\title{
A ESCRITA DE SI COMO MECANISMO DE MEMÓRIA EM MANO, A NOITE ESTÁ VELHA, DE WILSON BUENO
}

\section{THE WRITING OF SELF AS A MEMORY MECHANISM IN MANO, A NOITE ESTÁ VELHA BY WILSON BUENO}

\begin{abstract}
ACHRE, Simone Pinheiro ${ }^{1}$
RESUMO: O livro póstumo de Wilson Bueno, Mano, a noite está velha (2011) traz um narrador-personagem, chamado Frederico Souza de Oliveira. Esse personagem apresenta, como ele mesmo afirma, uma "conversa no escuro". No entanto, ao longo da escrita, o que se percebe é a prática de um monólogo, afirmativa possível visto que se tem uma narrativa em primeira pessoa. O enredo é composto por memórias da vida do protagonista, fatos do cotidiano daquele que os viveu que envolvem o leitor e que demonstra que o ato de escrever é o de conhecer-se a si mesmo.
\end{abstract}

PALAVRAS-CHAVE: Escrita, memória, literatura brasileira, Bueno.

ABSTRACT: Wilson Bueno's posthumous book Mano, a Noite está Velha (2011) brings a storyteller-character called Frederico Souza de Oliveira. This character presents, as he himself affirms, a "conversation in the dark". However, throughout the writing, what it is perceived is the practice of a monologue, affirmative possible since one has a narrative in the first person. The plot is composed of memories of the protagonist's life, facts of the daily life of the one who lived them that involve the reader and that demonstrates that the act of writing is to know itself.

KEYWORDS: Writing, memory, brazilian literature, Bueno

\section{INTRODUÇÃO}

Michel Foucault (2004), em “A escrita de si”, observa que, desde Sêneca, Plutarco e Marco Aurélio, a escrita já desempenhava um papel importante para a vida ascética e, para

\footnotetext{
${ }^{1}$ Mestre em Letras pela Universidade Estadual do Centro Oeste - UNICENTRO, graduada em Letras pela Universidade Federal da Fronteira Sul - UFFS. E-mail: simone_achre@yahoo.com 
exemplificar, traz os hupomnêmata e as correspondências. Sobre a primeira, aponta o caráter de instrumento técnico de registro:

Os hupomnêmata, no sentido técnico, podiam ser livros de contabilidade, registros públicos, cadernetas individuais que serviam de lembrete. Sua utilização como livro de vida, guia de conduta parece ter se tornado comum a todo público culto. Ali se anotavam citações, fragmentos de obras, exemplos e ações que foram testemunhas ou cuja narrativa havia sido lida, reflexões ou pensamentos ouvidos ou que vieram à mente. Eles constituíam a memória material das coisas lidas, ouvidas ou pensadas; assim, eram oferecidos como um tesouro acumulado para a releitura e meditação posteriores. Formaram também uma matéria prima para a redação de trabalhos mais sistemáticos, nos quais eram dados os argumentos e meios para lutar contra uma determinada falta (como a cólera, a inveja, a tagarelice, a lisonja) ou para superar alguma circunstância difícil (um luto, um exílio, a ruína, a desgraça). (FOUCAULT, 2004, pp.147-148).

Quanto às correspondências, Foucault (2004) enfatiza a questão voltada para o processo pessoal da escrita:

As cadernetas de notas que, nelas mesmas, constituem exercícios de escrita pessoal, podem servir de matéria-prima para textos que serão enviados a outros. Em troca, a missiva, texto por definição destinado a outro, também permite o exercício pessoal. É que, como lembra Sêneca, ao escrever, se lê o que escreve, do mesmo modo que, ao dizer alguma coisa, se ouve o que se diz. A carta que se envia age, por meio do próprio gesto da escrita, sobre aquele que a envia, assim, como, pela leitura e releitura, ela age sobre aquele que a recebe. Nessa dupla função a correspondência está bem próxima dos hupomnêmata. (FOUCAULT, 2004, p. 153).

Em Mano, a noite está velha (2011), o procedimento é semelhante ao apontado por Foucault (2004), pois Frederico, ao escrever os fatos do seu cotidiano, deixa traços, registros, ao mesmo tempo em que reflete acerca de sua vida.

Dizem que, depois da internet, ninguém mais escreve cartas, Mano. Eu é que não vou me envolver, a essas alturas da vida, com essas máquinas 
tresloucadas. E nem preciso delas, dispensáveis em meu cotidiano que necessita apenas uma caneta ou um lápis, cadernos, papéis, a reandar através deles a memória da casa e do que foi não só a memória da casa, mas a vida que por ela passou e hoje tende a noticiar não mais que a velhice, e a nenhuma esperança. (BUENO, 2011, p. 53).

E assim, a narrativa vai sendo tecida. $\mathrm{O}$ ato de escrever, ler e refletir de Frederico condiz com os dois processos apontados por Foucault (2004), que exemplifica esse processo ao mencionar os textos de Epícteto, em que a escrita está associada ao ato da meditação, ao pensamento sobre aquele que escreve e reativa o que ele sabe e, dessa maneira,

[...] torna presentes um princípio, uma regra ou um exemplo, reflete sobre eles, assimila-os, e assim se prepara para encarar o real. Mas também se percebe que a escrita está associada ao exercício de pensamento de duas maneiras diferentes. Uma toma a forma de uma série 'linear'; vai da meditação à atividade da escrita, e desta ao gummazein, quer dizer, ao adestramento na situação real e à experiência: trabalho de pensamento, trabalho pela escrita, trabalho na realidade. A outra é circular: a meditação precede as notas, que permitem a releitura, que, por sua vez, revigora a meditação. Em todo caso, seja qual for o ciclo de exercício em que ela ocorre, a escrita constitui uma etapa essencial no processo para o qual tende toda a askêsis: ou seja, a elaboração dos discursos recebidos e reconhecidos como verdadeiros em princípios racionais de ação. Como elemento de treinamento de si, a escrita tem, para utilizar uma expressão que se encontra em Plutarco, uma função etopoiéitica: ela é operadora da transformação da verdade em êthos. (FOUCAULT, 2004, p. 147).

Foucault (2004, p. 149) aponta a escrita dos Hupomnêmata, ou seja, dos registros e anotações deixados em cadernos ou em livros para que se pudesse voltar a eles sempre que necessário, e demonstra que a prática implica a leitura. Esse processo é verificado no decorrer do livro, uma vez que Frederico escreve e é esse ato, ao mesmo tempo, leitura e reflexão acerca do que está sendo realizado, como se lê em “[...] aqui, esta inútil escrivaninha quem nela escreveu uma única carta?” (BUENO, 2011, p. 07). 
Acerca da escrita de correspondências, Foucault (2004, p.153) descreve que esse tipo texto, por definição destinado a outro, também permite o exercício pessoal. Como afirmado anteriormente, não se tem claro se o texto escrito por Frederico é uma carta ou diário, estando o texto no limiar entre um e outro. Percebe-se, por exemplo, a falta de alguns elementos que seriam a base para a composição de algum gênero fixo: data, local - no caso da carta e do diário; assinatura, saudação, mais especificamente no caso da primeira. No entanto, o tom íntimo que compõe o enredo, e é característico tanto do diário pessoal quanto da carta, atravessa o relato com acontecimentos do dia a dia e a reflexão a respeito deles.

Há três dias não me olho ao espelho, há três dias não tomo banho, não faço a barba nem troco de roupa. Devo estar horrível. Fumo, compulsivamente fumo um cigarro atrás do outro e o inevitável ventilador do teto, com seu ruído rascante, torturado, transtorna ainda mais o janeiro espedaçado. Fiz, com má vontade ou por pura incompetência, um café ralo, a reutilizar um coador de papel, enganei o estômago com um resto de arroz frio e vagamente azedo que encontrei no fundo da geladeira. (BUENO, 2011, p. 143).

Em uma outra passagem, o narrador aponta que ele está realizando um “[...] diálogo com os mortos" (BUENO, 2011, p. 11), ou seja, o próprio Frederico dá o indício de que sua escrita ao irmão morto transforma-se em um monólogo. É esse processo, essa necessidade de conversar com os mortos que, de acordo com Wilson Bueno, fornece uma sobrevida aos mortos, o que se dá com a escrita/linguagem, pois é ela que dá, também, uma sobrevida, uma sobrevivência ao autor, à literatura.

Diálogos - monólogos, a rigor, no escuro -, alguma vez conspícuos, fragmentos, a prosa ligeira, ou aquela que se estende a cavalo da noite, com um cadáver predileto, escolhido a dedo, na prateleira de cima da estante Cortázar, um volume de Cortázar, falando de Paris e das ruas de Paris e dos bairros e dos cafés fumegantes e dos sucessivos Gauloises, meu Deus, Bolaño, até quando só nos entenderão os mortos que deambulam esta sala onde acabou ficando a escrivaninha, só sei escrever nela, Mano, como se em qualquer outro lugar fosse impossível brotar da caneta velha essa conversa aqui, contigo, no escuro, Mano, esta sala, os móveis antigos, a escrivaninha meio cafona, e lançam, os móveis, as cadeiras de espaldar alto, quando é noite lançam a sua 


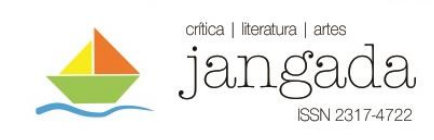

grande sombra sobre as paredes da sala, os mortos, Mano, esses mortos todos que não morreram nunca inteiramente nem morrerão de vez. (BUENO, 2011, pp.12-13).

Nessa reflexão sobre a literatura, ou melhor, sobre a sua sobrevivência, lê-se em outra passagem da narrativa quem seriam esses mortos, os que sobreviveram/sobrevivem pela escrita: "Semana passada contei - de Cervantes a Balzac, de Alencar a Borges, quinze conversamos no escuro" (BUENO, 2011, p. 11). Tais "conversas no escuro" podem ser consideradas como um indício das leituras realizadas pelo narrador-personagem. Com relação ao processo de escrita/reflexão, Foucault (2004) descreve que é a partir da escrita que se torna possível recorrer a uma memória do lido, da biblioteca daquele que escreveu, que fez as anotações.

Dessa forma, é possível voltar às anotações não mais como a pessoa que as escreveu, mas a que, ao fazê-lo, foi transformada por ela. Em consonância com essa concepção de Michel Foucault (2004), Walter Benjamin (2012), em Rua de mão única, postulou que o escritor deve manter seu caderno de notas tão rigorosamente quanto a autoridade constituída mantém o registro de estrangeiros. Nesse sentido, ele poderá consultá-lo, revê-lo e voltar a ele quantas vezes lhe forem necessárias, ainda que “[é] indizivelmente concernida pelo acontecer e pelas palavras trocadas e, quando se levanta, está totalmente coberta pela neve do lido." (BENJAMIN, 2012, p. 37). Ou seja, não é a mesma pessoa que havia iniciado a leitura, mas a que foi transformada por ela durante o processo de escrita/leitura. Foucault (2004) descreve esse processo de metamorfose pelo qual aquele que escreve ao mesmo tempo lê, e aquele que lê a escrita de outro é transformado por ela. Essa concepção de metamorfose concorda com o que Benjamin (2012, p. 102) postula “[...] quando, em seu interior, passava a mão de um vidro a outro, ia me transformando". Dessa maneira, verifica-se na narrativa de Wilson Bueno que a escrita age sobre aquele que escreve, assim como, Michel Foucault (2004) nos ensina com as correspondências e os hupomnêmata.

Como já foi mencionado anteriormente, o processo de leitura e escrita pode ser pensado como o acesso à biblioteca que formou aquele que registrou no caderno de notas ou na correspondência, suas impressões, ideias e leituras. Seguindo essa reflexão, Walter Benjamin (2012) confirma que

[...] todo o essencial encontra-se na caixa de fichas do pesquisador que o escreveu e o cientista que nele estuda assimila-o ao seu próprio fichário e nele 


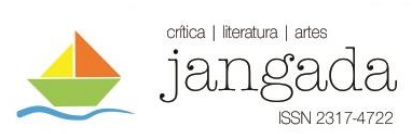

pode-se encontrar um possível indício do que lhe causa o trauma. (BENJAMIN, 2012, p. 102)

O filósofo alemão ainda continua refletindo sobre os rastros que são deixados, não somente pela escrita, mas, também, pela conversa, pela voz humana: “[...] a causa pode estar na construção do aparelho ou de minha recordação - o certo é que, em seu eco, os ruídos das primeiras conversas telefônicas permanecem em meus ouvidos muito distintos dos de hoje." (BENJAMIN, 2012, p. 79). Essa memória, esse vestígio do passado, pode se apresentar na forma de "[...] uma palavra, um rumor um palpitar, aos quais se confere o poder de nos convocar desprevenidos ao frio jazigo do passado, de cuja abóboda o presente parece ressoar apenas como um eco". (BENJAMIN, 2012, pp. 89-90).

Partindo dessas reflexões, pode-se afirmar que Bueno/Frederico/a literatura dá-se a conhecer pela escrita. E, a partir dela, pode-se recuperar a memória de outros autores que contribuem para a formação e a manutenção da literatura. Recuperar outros autores pela escrita, não é um ato involuntário ou imparcial, mas uma "[...] ação racional pela apropriação, unificação e subjetivação de um já dito fragmentário e escolhido.” (FOUCAULT, 2004, p. 162). O processo de recuperar outros textos, outros autores, é algo inerente à escrita. Benjamin (2012) apontou que a técnica dos dadaístas já havia sido empregada por Mallarmé mas, ao utilizar algumas de suas características, os poetas apropriaram-se delas e as atualizaram como um mecanismo que pode ser realizado de maneira inconsciente ou consciente. Frederico deixa subentendido que leu alguns dos escritores mais emblemáticos da literatura ocidental: "Semana passada contei - de Cervantes a Balzac, de Alencar a Borges, quinze conversas no escuro." (BUENO, 2011, p. 11). Todos são os interlocutores do protagonista, que, ao mesmo tempo, demonstra como se constitui o arquivo, a memória da escrita, visto que os autores já morreram, mas suas obras permaneceram.

Outro aspecto importante da escrita de si que se pode ler na escritura de Frederico é o uso de "[...] todo um conjunto de anotações sutis sobre o corpo, a saúde, as sensações físicas, a dieta, os sentimentos [que] mostram a extrema vigilância de uma atenção que está intensamente focalizada em si mesmo" (FOUCAULT, 2004, p. 160). O olhar para si, para como esse "eu" se vê diante do mundo é feito de forma crítica, só possível pelo "[...] correto distanciamento" (BENJAMIN, 2012, p. 56). É necessário perceber que a realidade não condiz com as imagens que são propagadas pelas mídias, pela cultura da estética e pela vida baseada na busca pela 
perfeição. Com Foucault e Benjamin, adentra-se mais uma vez na "conversa" de Frederico, que revela como se dá esse olhar para si, esse estar diante de si.

No vestir, sabe você, Mano, sempre fui um pouco desleixado, do mesmo modo com o corpo. Mas não abdico os paletós que nunca fecham e se fechassem sobre a barriga infame seria ainda mais sórdido. Pelo menos não mantenho de dia o pijama com que passei a noite, a exemplo da maioria dos aposentados. Fumo muito, me horrorizam os exercícios físicos, tão na moda hoje em dia. Morremos do mesmo jeito, atletas e sedentários. Nunca esquecer - inventamos a cultura da simetria, Mano. [...]. Mesmo sabendo que você não morre mais, lhe desvelarei a minha vida íntima [...]. (BUENO, 2011, p. 14).

Encontra-se, ainda, a questão da prática, o processo de escrita, o exercício, pois, segundo Foucault (2004):

Nenhuma técnica, nenhuma habilidade profissional pode ser adquirida sem exercício; não se pode mais aprender a arte de viver, a technê tou biou, sem uma askêsis que deve ser compreendida como um treino de si por si mesmo. (FOUCAULT, 2004, p. 146).

Essa questão relacionada ao treino de si também pode ser lida em Benjamin (2012, p.192) “[...] muita coisa é inata, mas muito é feito pelo treinamento". A referência de escrita como processo de aprimoramento, como um treino de si por si mesmo, também pode ser observada em Bueno (2011):

Eu não sou um escritor que escreve como seus contemporâneos; nem escritor nunca fui, Mano, só um leitor compulsivo e capaz de alguma audácia, como essa escrita aqui no escuro, e alguns diletantismos pelo passado. (BUENO, 2011, p. 76).

Mais uma vez, pode-se ler o treino da escrita por si mesmo, quando Frederico reflete acerca do ato de escrever que realiza: "E nisso de sequestrar o leitor tenho alguma experiência. Amadora sem dúvida, mas a prática, mesmo que escassamente conhecida e baldia de reinventar os dramas, melodramas [...]" (BUENO, 2011, p. 16). Dessa forma, o ato de aprimorar-se 


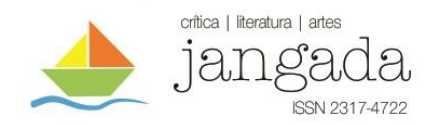

enquanto escritor é ao mesmo tempo um ato de leitura, ou seja, para escrever é necessário ler. Essa mesma concepção ocorre na correspondência, analisada por Foucault (2004), em que ele afirma:

É que, como lembra Sêneca, ao se escrever, se lê o que se escreve, do mesmo modo que, ao dizer alguma coisa, se ouve o que se diz. A carta que se envia age, por meio do próprio gesto da escrita, sobre aquele que a envia, assim como, pela leitura e releitura, ela age sobre aquele que a recebe. Nessa dupla função a correspondência está bem próxima dos hupomnêmata, e sua forma muitas vezes se assemelha a eles. (FOUCAULT, 2004, p. 153)

Assim, ao escrever ao irmão morto Frederico escreve, reflete e medita, como em "Sempre julguei um pouco ridícula essa espécie de lembrança. Nunca pensei, Mano, que as teria também, feito agora tenho [...]" (BUENO, 2011, p.56). Esses dois processos são observados a partir da reflexão que a escrita das memórias lhe permite retomar e rever criticamente suas atitudes e decisões, como em:

[...] nutrimos a memória com que existiram e, por vezes, desconfiamos de nós mesmos - se somos os mortos que evocam os vivos já mortos ou se os vivos ante a grandiosa exasperação de sermos efetivamente os vivos que fazem viver os mortos através dessa mesma memória, cambiante, difusa - feito um alvoroço de passarinhos. (BUENO, 2011, p. 57).

E é pelo ato de escrever que o narrador de Mano, a noite está velha (2011) passa a unir os destroços de sua história e a "[...] unificar esses fragmentos heterogêneos pela sua subjetivação no exercício da escrita pessoal" (FOUCAULT, 2004, p. 152). Além disso, ele ainda revê suas práticas, reflete por meio da escrita que resgata as memórias: o presente que requer o passado, pois este é parte constituinte dele, ao mesmo tempo em que:

As últimas linhas da carta mostram bem como ela se articula com a prática do exame de consciência: o dia termina, logo antes do sono, com uma espécie de leitura do dia decorrido: desenrola-se aí em pensamento o rolo em que estão inscritas as atividades do dia, e é este livro imaginário da memória que é reproduzido no dia seguinte na carta dirigida àquele que é ao mesmo tempo o mestre e o amigo. (FOUCAULT, 2004, p. 161). 
Esse ato de escrever sobre si, sobre suas memórias, liberta o narrador de tudo que o incomoda, de suas angústias, daquilo que o faz sentir-se culpado, pois lhe proporciona dividir suas aflições com um outro por meio da escrita, o que torna o fardo menos pesado. Tal concepção de escrita está de acordo com o postulado por Foucault (2004), quando estabelece que:

A escrita de si mesmo aparece aqui claramente em sua relação de complementariedade com a anacorese: ela atenua os perigos da solidão; oferece aquilo que se fez ou se pensou a um olhar possível; o fato de se obrigar a escrever desempenha o papel de um companheiro, suscitando o respeito humano e a vergonha; é possível então fazer uma primeira analogia: o que os outros são para o asceta em uma comunidade, o caderno de notas será para o solitário. Mas, simultaneamente, é levantada uma segunda análoga, que se refere à prática da ascese como trabalho não somente sobre os atos, porém mais precisamente sobre o pensamento: o constrangimento que a presença do outro exerce na ordem da conduta, a escrita exercerá na ordem dos movimentos interiores da alma; nesse sentido, ela tem um papel muito próximo da confissão ao diretor espiritual sobre a qual Cassiano dirá, na linha da espiritualidade evagriana, que ela deve revelar, sem exceção, todos os movimentos da alma (omnes cogitationes). (FOUCAULT, 2004, p. 145).

Observa-se que o ato de lembrar só é possível diante de um corpo que teve uma experiência. No caso de Frederico Souza de Oliveira, a experiência foi despertada pelo trauma da morte do irmão. Wilson Bueno, com esse narrador-personagem intimista que é Frederico, aproxima-se da reflexão elaborada por Michel Foucault (2004, pp. 145-146), pois o narrador sente a necessidade de escrever como quem desabafa com um amigo, para livrar-se daquilo que o perturba. Em Mano, a noite está velha (2011), a necessidade de contar algo, de se livrar dos sentimentos que incomodam o narrador é recorrente, como quando ele apresenta os motivos que o levam a escrever: "Escrevo para não esquecer de todo, não esquecer de mim mesmo nesta casa [...]” (BUENO, 2011, p. 47).

Michel Foucault em seu texto "A escrita de si” (2004, p. 157) alega que o procedimento de escrita é um ato de reconhecer a si, as suas dificuldades, os seus sentimentos, as coisas que 
viu e viveu, os lugares por que passou. A escrita de si é como dar-se a conhecer a si e ao outro, pois, ao escrever, o narrador-personagem utiliza-se de memórias oriundas de experiências, que são a matéria prima de sua escrita: "Lembrar e escrever; escrever e lembrar." (BUENO, 2011, p. 52).

Foucault (2004, p. 153) aponta a escrita como arquivo que guarda as memórias oriundas das experiências vividas e postula que a memória e a escrita sempre estiveram ligadas, sendo que, para ele, essas memórias escritas “[...] podem servir de matéria prima para textos que são enviados a outros", como também acontece com Frederico:

Em verdade vos digo, nem mesmo eu que escrevo sei para quem estou escrevendo, Mano. O primeiro leitor objetaria que escrevo a você, Mano, que escrevo a você esta ladainha merencória. Mas como é para você, Mano, se ouvir, para você, virou um verbo abusado se não metáfora absurda a carregar em si uma mentira sem honra nem grandeza? Mentindo a mim mesmo, alinhavo frases, longos períodos, parágrafos sujos ante o medo e a ignorância de que escrever é para os gênios e não para um poeta em tom menor feito este que lhe escreve, Mano, poeta de fim de semana, sonetista atabalhoado, alguma crônica publicada nos jornais da faculdade, e as centenas de discursos parlamentares, como fiel servidor, ora aposentado, do legislativo da Aldeia. (BUENO, 2011, pp. 40-41).

Ao escrever suas memórias, Frederico passa ao processo de articular as palavras para organizá-las e transmitir aquilo que lembrou. Sua escrita é composta de maneira a autenticar os fatos lembrados e persuadir a si mesmo a acreditar na palavra. Para isso, o uso dos verbos na primeira pessoa do singular aponta para a idoneidade que cerca aquele que diz ser o dono das memórias do "eu" que as viveu, logo, não pode ser contestada: "E o menino que não tinha nove anos acabei trazendo-o à casa do Champagnat, contratei cuidadora e lhe dei, enquanto aqui esteve, diálogo, afeto, educação escolar.” (BUENO, 2011, p. 23). Mas o que atesta a veracidade do que está sendo dito, nada mais é do que, nas palavras de Jeanne Marie Gagnebin (2009, p. 39), em Lembrar escrever esquecer, uma vontade de verdade: "Entendo com isso que a verdade do passado remete mais a uma ética da ação presente que uma problemática da adequação (pretensamente científica) entre 'palavras' e 'fatos'.' 
Experiências pelas quais esse "eu" passou, ouviu de outros, leu em livros, somente para citar algumas fontes, a percepção, o distanciamento daquilo que outrora foi presente aparecem na narrativa de Frederico, ao relatar que: "Sem você, para ele, o Pai, ficou então igual que você nunca houvesse existido. A mim mesmo, confuso e agressivo, o Pai achava que dele eu era o irmão mais novo.” (BUENO, 2011, p. 10). É, pois, do ponto de vista do narrador que a imagem do pai é construída.

A memória corporal também carrega a memória dos lugares percebida por um ponto de vista singular. Essa memória construída dos lugares apresenta a transformação do espaço ao redor, o que confere certa veracidade, como se observa na seguinte passagem: “[...] aquele mesmo que um dia, meninos e migrantes do Norte pioneiro, chamamos Bigorrilho. Agora o bairro metido a besta se chama Champagnat, com a devida pronúncia francesa" (BUENO, 2011, p. 10). Essa memória construída de que o sujeito melancólico se serve, confere legitimidade ao próprio enunciado quando lembra. Ele viu, ele ouviu, ele leu, ele esteve lá, portanto, assume que é verdade, por isso vale repetir a citação anterior: "Agora o bairro metido a besta se chama Champagnat, com a devida pronúncia francesa” (BUENO, 2011, p. 10).

A "prosa ligeira" (BUENO, 2011, p. 12) de Frederico inicia com a frase: "Mano, agora que você não morre mais, entabulo contigo esta conversa no escuro" (BUENO, 2011, p. 07). A palavra "conversa" enfatiza o tom íntimo que pode ser dirigido a um interlocutor, seja ele fictício ou real, presente ou ausente fisicamente ou mentalmente, como o próprio autor da escrita pois, ao escrever, ele lê.

Segundo Jeanne Marie Gagnebin (2009), desde Homero a linguagem era o meio pelo qual os heróis sobreviveram ao tempo; a oralidade era o meio de transmissão das experiências, tinha um cunho pedagógico que era mantido por meio das palavras do poeta: "A palavra do poeta, palavra de rememoração e de louvor, mantém viva a glória do herói morto, cuja lembrança mergulharia, sem ela, no esquecimento pior que a morte física" (GAGNEBIN, 2009, p. 195). Do mesmo modo, nosso herói moderno, Frederico, também mantém vivo o passado pela palavra que ultrapassa a morte física. E assim, ao escrever/narrar todas as coisas que dá a entender que não contou ao irmão em vida, liberta-se, revela-se e exibe-se como se observa em:

Adulto, agora lembro, continuaram a assustá-lo, mesmo os vira-latas do bairro. Levava sempre a mão ao pescoço, desconfortável, como esquecer?, quando cruzava com dobermans ou rotweillers dos vizinhos da mansão em frente, puxados pela coleira; pela coleira, mas dobermanns, pit bulls, 


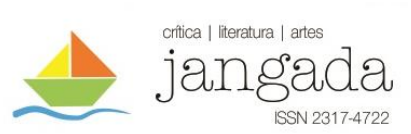

rotweillers. Desviava calçadas, fingindo indiferença; desconversava. Embora tudo isso vos esteja sendo explicitado agora, agora que você não morre mais nem se escandaliza, e guarda para sempre o meu e o teu segredo, Mano. O segredo escuso dos Souza de Oliveira. Agora, sim, posso me revelar em você, sem pejo, a nossa ópera chulé. (BUENO, 2011, pp. 24-25).

Dessa forma, Frederico transfere para a escrita seus anseios, suas confissões e revê suas experiências. Os motivos que podem fazer com que ele escreva são livrar-se daquilo que o incomoda pois, ao escrever, ele compartilha suas dores e angústias: “[...] anoto aqui mais pelo desconforto que me causa, bicho sensível, e os meus nada secretos medos de que a cidade acabe por engolir a nossa casa (BUENO, 2011, p. 10) e a busca pelo perdão: "Perdão, Mano, por imaginá-lo eterno. Por desconsiderar que, a respeitar fronteiras, religioso nessa sua crença de não falhar nunca, você também hesitava, temia lá o seu temor de macho ocidental" (BUENO, 2011, p. 24).

A ação de narrar o que é inenarrável aproxima-se das reflexões realizadas por Walter Benjamin (1994), no seu ensaio de 1936, "O narrador”, no qual salienta que, após a Segunda Guerra Mundial, a transmissão por meio do ato de contar oralmente histórias e experiências bem como a concepção do sujeito racional entraram em decadência, o Iluminismo precisou conviver com o fracasso de seus ideais e, com isso, se deu a morte do narrador e o declínio da experiência. Para Benjamin (1994), o sujeito que viu as atrocidades cometidas durante a guerra calou-se, emudeceu por não poder ou não querer reviver as experiências oriundas dos campos de batalha. E, ao rememorar os momentos de dor e sofrimento, o narrador de Mano, a noite está velha (2011), confessa: "E eu, Mano, mais que a você, me recusei a vê-lo porque nem podia supor que a morte também em você já pusesse ovos, ovos de escorpião” (BUENO, 2011, p. 23).

Segundo Gagnebin (2009), o ser humano inventa estratégias para que suas experiências sejam passadas e se perpetuem através dos tempos: "Criamos, assim, centros de memória, organizamos colóquios, livros [...]" (GAGNEBIN, 2009, p. 97), outras formas de narrar, com a escrita. Nesse sentido, o protagonista do romance de Bueno utiliza-se do texto escrito para narrar suas histórias, suas experiências.

Dessa forma, ao escrever suas memórias, o protagonista de Mano, a noite está velha (2011) vasculha no passado em busca de fragmentos, a exemplo do trapeiro de Benjamin que revira o lixo, as ruínas, tirando de suas experiências e daquilo que o incomoda, que é motivo de dor e de sofrimentos, o material para compor a sua narrativa. Com isso, observa-se que o 
narrador-personagem, Frederico, não é aquele narrador tradicional, e sua escrita também não segue os padrões tradicionais, que preconizavam uma história linear, mas se apresenta como uma narrativa fragmentada, que não é dividida em capítulos, mas sofre cortes que, em muitos casos, são bruscos, como se passassem de uma memória à outra sem a exigência de uma ligação entre elas. Como uma colcha de retalhos, ele vai costurando cada fragmento para compor o todo. Por mais pequena que seja, cada lembrança é importante para constituir o enredo. Esse processo de montar a história a partir das ruínas é descrito por Gagnebin (2009):

Ao juntar os rastros/restos que sobram da vida e da história oficiais, poetas, artistas e mesmo historiadores, na visão de Benjamin, não efetuam somente um ritual de protesto. Também cumprem a tarefa silenciosa, anônima mas imprescindível, do narrador autêntico e, mesmo hoje, ainda possível: a tarefa, o trabalho de apokatastasis, essa reunião paciente e completa de todas as almas do Paraíso, mesmo das mais humildes e rejeitadas, segundo a doutrina teológica (julgada herética pela Igreja) de Orígenes, citado em mais de uma passagem por Benjamin. Hoje não existe mais nenhuma certeza de salvação, ainda menos de Paraíso. No entanto, podemos - e talvez mesmo devamos continuar a decifrar os rastros e a recolher os restos. (GAGNEBIN, 2009, p. 118).

Jeanne Marie Gagnebin (2009) em seu estudo, “[...] esboça como que a ideia de uma outra narração, uma narração nas ruínas da narrativa, uma transmissão entre os cacos de uma tradição em migalhas" (GAGNEBIN, 2009, p. 53). Esse processo é distinto do contador de histórias tradicional, mas nem por isso deixa de comunicar, de narrar. Segundo Gagnebin (2009), “[...] a escrita foi, durante muito tempo, considerada o rastro mais duradouro que um homem pode deixar, uma marca capaz de sobreviver à morte de seu autor e de transmitir sua mensagem” (GAGNEBIN, 2009, p. 112). Por outro lado, Benjamin (2012) aponta o caráter imagético e representativo da imagem, ao afirmar que:

O que a madona bizantina tem nos braços é apenas um boneco de madeira em tamanho natural. Sua expressão de dor ante um Cristo cuja condição de criança permanece apenas sugerida, apenas representada, é mais intensa do que ela jamais poderia ostentá-la com uma imagem verdadeira de menino. (BENJAMIN, 2012, p. 49). 
Logo, só há memória de algo que foi presente, mas não o é mais, que pertence a outro tempo, mas se faz presente e continua fazendo sentido no agora. Por isso a necessidade de uma distância temporal. Ao ser recordado, o passado é presentificado: o ausente se torna presente e é atualizado, não como foi literalmente, mas, como o presente o compreende.

Ainda sobre a questão de memória como registro, o crítico francês Georges DidiHuberman, em "Remontar, remontagem (do tempo)", texto publicado em 2007 na revista Étincele, no qual o filósofo aponta que a memória é imagem, e essa por sua vez pode ser entendida como linguagem, pois, ambas são indissociáveis. Dessa forma, percebe-se que há uma aproximação no raciocínio dos dois autores ao pensar e refletir sobre a questão da memória como algo criado a posteriori, ou seja, montado, construído pelo homem; não uma cópia fiel ao original, mas uma criação oriunda do que é lembrado.

Em Mano, a noite está velha (2011), o narrador-personagem rememora, busca em suas memórias, de modo consciente: "Esta história desenxabida que, sem outra ocupação, ou terapia, mergulho nela - Kamikase suicida. Agora sim eu posso inventá-los à vontade fazer de suas vidas o que eu quiser" (BUENO, 2011, p. 52). Mas, ao mesmo tempo, essas memórias lhe retornam acionadas por outros meios, por outros sentidos possíveis através do corpo, que sente as dores da solidão, da morte etc. A exemplo disso, tem-se a memória acionada pelo olhar, como quando encontra uma foto: "Dia desses, o retrato, não sabido, dentro de um velho livro. [...]. Desviro o retrato num gesto autômato. Nele estamos nós: um longínquo domingo no Passeio Público.” (BUENO, 2011, p. 61).

Esse processo de lembrar passagens e lugares pode ser lido na narrativa de Frederico, pois cada um desses locais traz consigo memórias de situações vividas, de pessoas ligadas a eles. Em uma das suas memórias, o narrador descreve os cantos da casa em que o habitar ou ter habitado um lugar deixa marcas ao mesmo tempo em que é marcado por ela: "[...] tão triste como olhar demoradamente os cantos da casa. Não, não olho mais, Mano, os cantos da casa. Há neles uma coisa assim como uma espécie única de solidão, a solidão dos cantos da casa" (BUENO, 2011, p. 08). Assim, quando Frederico descreve os espaços da casa traz outras marcas que são percebidas pela memória.

De acordo com Gagnebin (2009) " [...] a escrita não é mais um rastro privilegiado, mais duradouro do que outras marcas da existência humana" (GAGNEBIN, 2009, p. 113), os rastros não são criados, mas deixados sem intenção de fazê-los e, por isso mesmo, eles podem ser 
usados contra quem pertenciam. Tal qual aparecem na narrativa do protagonista, são os vazios não mais habitados pelos demais membros da família que carregam e trazem as marcas daqueles que neles viveram. Gagnebin (2009) cita Benjamin para indicar que os rastros se aproximam dos lixos, dos restos, das ruínas deixadas. Segundo ela, o autor encontra, nesses destroços, o material para tecer a sua obra de arte e é por eles que se ouve a voz dos esquecidos, das vítimas, daqueles que não podem mais fazer-se ouvir, tal qual o narrador que teria morrido:

O narrador também seria a figura do trapeiro, do Lumpensammler ou do chiffonnier, do catador de sucata e de lixo, esta personagem das grandes cidades modernas que recolhe os cacos, os restos, os detritos, movido pela pobreza, certamente, mas também pelo desejo de não deixar nada se perder [...].(GAGNEBIN, 2009, p. 53-54)

O papel daquele que junta os destroços é realizado pelo personagem Frederico. Seu texto é escrito a partir de fragmentos de memórias, partes que são retomadas e posteriormente sofrem uma ruptura; na sequência, passa-se à descrição de outras memórias em um outro momento. Ao longo do enredo, esses fragmentos de memória são retomados. Por exemplo, é possível citar as várias vezes em que ele retoma a lembrança da amiga Hilda, "Zonza, a Hilda agarrou em mim" (BUENO, 2011, p. 68), depois “A Hilda... Ah, a Hilda! Coitada da Hilda.” (BUENO, 2011, p. 79), mais adiante, volta citá-la "Nem a Hilda está mais aqui.” (BUENO, 2011, p. 140), só para elencar algumas passagens. Essa repetição acontece em meio a outras lembranças, que são citadas mais de uma vez ao longo do enredo. O retorno ao passado traz consigo outra forma de a memória se estabelecer, pois, com os lapsos, uma lembrança aciona outras lembranças. Aquele que lê pode ir buscar quem é essa Hilda, ou, ainda, aquele que lembra pode ativar outras imagens que são acionadas a partir delas.

Como apontado anteriormente, as lembranças de lugares, coisas, sentimentos ou pessoas são acionadas, muitas vezes, pelo corpo; aparecem sem serem buscadas, a princípio, mas são acionadas pelos processos cognitivos, pelas sinapses que são acordadas pelo abalo causado por algo que surge, como um cheiro ou uma fotografia. No entanto, não são as mesmas sensações, impressões e sentimentos, pois como descrito por Benjamin (2012): “[...] como haveria eu de temperá-la com tudo aquilo que, naquela época, nela desfrutaste [...] (BENJAMIN, 2012, p. 224). Com relação a essa memória recuperada, Gagnebin (2009) cita o texto de Marcel Proust, Em busca do tempo perdido (publicado em 1909), e traz a passagem em que “[...] a 'madeleine' 
ressuscitou uma lembrança, esquecida no fundo da memória" (GAGNEBIN, 2009, p. 145), para, com isso, apontar a necessidade de lutar contra a morte por meio da escrita, de reconhecer que a morte e o tempo, realmente são outros, não voltam mais. Essas memórias acionadas involuntariamente, são "Libertadas por nós, venceram a morte e voltaram a viver conosco" (GAGNEBIN, 2009, p. 150).

Em Mano, a noite está Velha (2011), o narrador-personagem Frederico vivencia, para usar o termo de Gagnebin (2009), o sentimento oriundo da "madeleine", porém um pouco diferente. Ao invés de ter despertado uma memória pelo paladar, outros aspectos sensoriais são os motivos desencadeadores das memórias. Na passagem que segue, o destaque vai para o olfato:

Nascem pequenas flores ao redor do cipreste em frente. Em cheiro forte a jasmim entra na sala e me acorda o baixo-ventre. Taras antigas, desejo escabroso, uma matança de bois em Goiás, o gemido do carneiro degolado no fundo do quintal pelo Padre Quintas, em Aquidauana [...]. (BUENO, 2011, p. 25).

Em outra passagem, o cheiro o leva para o passado e o faz refletir acerca do presente, “[...] um cheiro rosa, Mano, que, discreto e rápido, deu lugar àquele velho cheiro, mais antigo que nós, adocicado e triste, [...] um cheiro a gaveta e mofo, nessa casa que o Pai um dia chegou a chamar palacete, acanhada construção de dois andares" (BUENO, 2011, p. 09).

$\mathrm{O}$ aspecto visual também é um dos agentes que despertam as memórias. Frederico, ao olhar para um retrato, é enviado para tempos de outrora e reflete:

Na foto antiga o que sobressaem são os lábios; murcharam agora, Mano, foram ficando, com o tempo, com o irrefletido caos das horas, mais finos - como se a eles todas as palavras os tivessem encolhido até aqui, os vitupérios, os escarros e o que a espessa saliva dos tabagistas sem cura, ao longo dos anos tempo, há quanto tempo? - vem umedecendo de suas babas e humores. (BUENO, 2011, p. 74).

Segundo Benjamin (2012), as memórias são constituídas de imagens e formam uma parte da história, esta vista por um ângulo apenas. Os sentimentos que uma mesma imagem 
pode produzir em duas pessoas não serão iguais; se o forem, não necessariamente serão pelos mesmos motivos. Frederico sente o desejo de voltar no tempo, desejo despertado pela fotografia, por aquilo que ela representa, bem como pelos sentimentos que ela desperta:

Só alimenta vitalmente a vontade representada. Com a mera palavra, em contrapartida, ela pode no máximo inflamar-se, para em seguida continuar a arder chamuscada. Não há vontade sã sem a exata representação imagética [...]. (BENJAMIN, 2012, p. 41).

Ao olhar para uma fotografia, alguns sentimentos são despertados, mas eles são distintos dependendo de quem olha e devido ao tempo que se passou entre o instante do flash da máquina e o presente do que está a olhar para a imagem. É o passado sendo visto pelos olhos do presente. Esse processo é realizado pelo narrador de Mano, a noite está velha (2011) pois, ao olhar para uma foto, lembra, mas esse ser de outrora não é mais o mesmo e pode realizar o ato de ver com as lentes da experiência:

[...] um longínquo domingo no Passeio Público. A foto é de uma beleza inesperada e exasperante. A mãe, em pé, na grama, a saia godê; o Pai, também ereto, o terno de paletó trespassado, a gravata, o chapéu; você de um lado e eu de outro, ambos de calças curtas, ambos de azul-marinho, o branco colarinho fechado. (BUENO, 2011, pp. 61- 62).

Essas lembranças não vêm apenas para mostrarem-se involuntárias, vêm para mostrar a sua relação com a morte, com aquilo que foi e não é mais, mas que, por meio da lembrança, é atualizado, presentificado e demonstra, ainda, a efemeridade da vida. $\mathrm{O}$ ato de rememorar benjaminiano, como descrito por Gagnebin (2009, p. 59), "Memória ativa que transforma o presente", é acionado pelo presente, mas, ao mesmo tempo o modifica, pois faz aquele que lembra não apenas reviver emoções, mas refletir sobre o vivido. No livro de Bueno, ao escrever, Frederico lembra uma passagem - a malhação de Judas - e compara o seu atual estado com o boneco.

O cadáver de um boneco, Mano? Lembro a malhação do Judas, mas àqueles Judas de nossa infância, no sábado de Aleluia, mesmo aos chutes e estraçalhados a paulada, ainda restava deles, me lembro, antes de incendiados, 
algum feitio ou talhe. O que sobrou de mim é só uma massa disforme. (BUENO, 2011, p. 141).

Ainda, como lembra Jeanne Marie Gagnebin (2009), a escrita é considerada “[...] o rastro mais duradouro que um homem poderia deixar, uma marca capaz de sobreviver à morte de seu autor e de transmitir uma mensagem" (GAGNEBIN, 2009, p. 113). Desse modo, o ato de lembrar e escrever é tido pelo protagonista como "Lembrar e escrever, escrever e lembrar" (BUENO, 2011, p. 52).

Em Mano, a noite está velha (2011), o protagonista Frederico tem consciência de que lembra, como lembra e como suas memórias, ao serem escritas, podem ser manipuladas de acordo com os seus interesses. O que é registrado por ele não pode ser contestado, uma vez que aquele que poderia fazê-lo está morto, não lhe responde. Além disso, pelo fato de que toda memória é também um ponto de vista, ela é questionável e não uma verdade absoluta, como descrita pelo narrador:

Logo vocês três serão apenas três nomes distintos e a memória que eu quiser inventar de nós, como se inventa um romance, a fraude de um documento histórico ou a fotografia - irascível - com que um documentário, por hipótese, tenta o registro do real [...]. (BUENO, 2011, p. 75).

Outro aspecto importante da escrita das memórias é deixar conhecer outras épocas, mas pelo viés da ficção. Não há verdades, não há relatos, testemunhos que não estejam preenchidos pelas memórias, sendo que estas são constituídas de imaginação. Assim, instaura-se a incerteza e abre-se espaço para a criação. Gagnebin (2009) recupera Benjamin para salientar a função da memória, mais precisamente desse corpo que lembra: “[...] o narrador e o historiador deveriam transmitir o que a tradição, oficial ou dominante, justamente não recorda" (GAGNEBIN, 2009, p. 54). Mas, por outro lado, "Tudo o que é recordado, pensado, conscientizado, torna-se alicerce, moldura pedestal, fecho de seus pertences" (BENJAMIN, 2012, p. 234), a base para que o outro olhar seja possível.

Em Mano, a noite está velha (2011), ao escrever suas memórias, Frederico volta para o passado e, com isso, faz uma leitura acerca da história do Paraná por meio das lembranças do cotidiano de pessoas comuns, relatando que o estado foi o destino de imigrantes que, aqui, fizeram sua morada. Há, com esse deslocar do olhar, outras realidades da mesma época que se 
contrapõem muitas vezes à história tida como oficial, que são mostradas e nem sempre apontam para a imagem do progresso e deslumbre que está, muitas vezes, atrelada aos discursos dos vencedores. Nas memórias do narrador-personagem, verifica-se aquilo que Benjamin (2012, p. 207) descreve como "Os arredores [que] são o estado de exceção da cidade".

Nas memórias de Frederico, pode-se ler, por meio da ficção, as dificuldades que os imigrantes enfrentaram para a adaptação no novo país, como lidavam com o idioma e como mantinham o contato com a língua materna. Também deixam transparecer uma crítica ao fato dos estrangeiros acharem que sabiam falar a língua melhor que os próprios nativos, como se ela pudesse ser padronizada, imposta, "E era curioso que aqueles meninos, que em casa falavam a língua arrevesada dos pais, nos corrigissem o português ordinário [...]” (BUENO, 2011, p. 71). Além desses fatos, pode-se verificar o convívio entre os povos e como se viam entre eles.

Era como se dissessem que uma coisa era desembarcar nela, na Aldeia, forasteiros; bem outra ver nelas nascer seus netos, bisnetos e até os tataranetos. A Aldeia era deles de um modo quase mesquinho. Como se isso conferisse aos imigrantes europeus, polacos principalmente, árabes, armênios, uma certidão de posse, a prevalência com que nos olhavam, de cima, os olhos azuis. Roceiros eles também, caipiras de outras plagas e sotaques. (BUENO, 2011, p. 69 [grifo nosso])

Por outro lado, o processo de migração também é apresentado por meio das memórias de Frederico, ao lembrar o percurso e os obstáculos que a sua própria família, os Souza de Oliveira, enfrentou. O narrador-personagem descreve como foi a mudança do lugar onde viveram e o faz questionando o irmão. Outro fator importante está ligado ao fato de a mudança ser vista como uma forma de "vencer na vida", o que demonstra que a ideia de grandes centros estava relacionada ao progresso e ao sucesso.

Lembra, Mano, lembra. Você era tão pequenino que se lembrar haveria de. Assim que o Pai arranjou o primeiro jeito de a gente vencer a Aldeia, duas ou três semanas depois do desembarque na estação ferroviária vindos do Norte vermelho, a cena, as cenas, os embates. (BUENO, 2011, p. 69) 
A questão do convívio de várias nacionalidades, como viviam, como eram os costumes, crenças, como viam umas às outras, também pode ser observada nas memórias de Frederico. $\mathrm{O}$ tom de hostilidade que enfrentavam e o processo de convívio entre eles, “-Polaco! O xingamento batia feito porrada. Sabíamos. -Negrada! A resposta vinha na fronteira do cuspo [...]. Em jogo, mais que a cor, o sentimento súbito de dignidade ameaçada” (BUENO, 2011, p. 70). Isso pode demonstrar que, mesmo estando em situações parecidas e condições semelhantes, as pessoas não se reconheciam uns nos outros. A partir dos relatos de Frederico, é possível associar a vinda de estrangeiros ao país com uma política que ocorreu na época, que visava à vinda de mão de obra barata para o Brasil, ao povoamento dos estados e ainda a uma tentativa de europeização do país.

É por meio da memória de Frederico que se constata como poderia ter ocorrido a troca de saberes, experiências e costumes na época:

Experimentava-se o pepino azedo a princípio com nojo e logo depois, gulosamente, e aprendíamos com os polacos a exata maturação das uvas nas parreiras improvisadas no fundo dos quintais. De cor fixava-se o tempo das maçãs, das peras e da ameixa-amarela. Com os polacos, a família se iniciava, Mano, paciente, na arte das compotas nos vidros Trevisan - enxutos, cristais, espelhos. (BUENO, 2011, p. 70-71)

Em outra passagem, verifica-se que Frederico reflete acerca daquele período, daquelas pessoas, da sua própria família e das atitudes que tinham. Demonstra, ainda, a heterogeneidade que forma o povo brasileiro e a história de vida do personagem, tudo o que ele foi ou é tem, em sua origem, o resultado do convívio com outras pessoas, da mescla de tradições, o que demonstra que nada se faz sozinho, pois o ser humano, como tal, é fruto da relação com o outro, é o produto de uma construção social adquirida durante a sua vida.

Renovava contudo a pergunta: como poderiam ser brasileiros aqueles seres brancos, frios e encapotados, de cabelos amarelos e olhos claros, tropeçando na língua embaralhada? Mas eram: na missa, no catequismos, nos casamentos, nas dificuldades pequenas do dia a dia, na pechincha e no circo, nas grandes bebedeiras e nos velórios. Mas o que persiste é a morte aterrada na manhã da nova cidade, o escuro do quarto e do coração apertado: 
-Polaca!

- Negrada! (BUENO, 2011, pp. 73-74).

Essas passagens que Frederico escreve acerca do passado, das vivências, de outras épocas, fazem parte de um relato de testemunho, pois ele esteve lá, viu e ouviu tudo o que contou e aponta a sua versão da História, o que lhe proporciona rever as suas práticas. Como um historiador benjaminiano, ele deve "[...] agir como um homem que escava" (BENJAMIN, 2012, p. 245), aproximando-se do próprio passado e o faz por meio da memória. Esta o faz conhecer-se a si e dá a conhecer-se ao outro pela escrita. No caso da narrativa, sabe-se que Frederico escreve ao irmão, mas não se tem claro se se trata de uma carta ou de outro gênero; sabe-se que ele escreve pensando no irmão que está morto, como fica evidente em "Mano, escrevo a você esta ladainha merencória" (BUENO, 2011, p. 41), ainda, indaga que "[...] aqui, esta quase inútil escrivaninha quem nela escreveu uma única carta?" (BUENO, 2011, p. 07), e aponta que os materiais que usa para escrever não são eletrônicos.

Dizem que, depois da internet, ninguém mais escreve cartas, Mano. Eu é que não vou me envolver, a essas alturas da vida, com essas máquinas tresloucadas. E nem preciso delas, dispensáveis em meu cotidiano que necessita apenas uma caneta ou um lápis, cadernos, papéis, a reandar através deles a memória da casa e do que foi não só a memória da casa, mas a vida que por ela passou [...]. (BUENO, 2011, p. 53).

Quando Frederico recorda, suas lembranças trazem à tona aquilo que o consome, o atormenta e, com isso, “[...] lembrar os defeitos do corpo na alma, a ação desta no corpo, a cura do primeiro pelos cuidados dispensados à segunda" (FOUCAULT, 2004, p. 158). Lembrar e escrever auxilia aquele que realiza a ação a reconhecer as angústias e frustrações daquilo que ele fez ou deixou de fazer. Segundo Benjamin (2012), o ato de recordar traz os indícios daquilo que perturba, que não foi totalmente resolvido, ou que foi o motivo dos sentimentos que acometem o ser no presente, "A causa pode estar na construção do aparelho ou de minha recordação - o certo é que, em seu eco, os ruídos [...] permanecem em meus ouvidos muito distintos dos de hoje”. (BENJAMIN, 2012, p. 79).

Constata-se, pela escrita de Frederico, que ele se sente culpado por não ter ficado ao lado de Maico, quando este estava à beira da morte: "Depois que lhe sumiram os olhos e eu 
mais que a você, me recusei a vê-lo [...]" (BUENO, 2011, p. 23). Ao lembrar e escrever, no entanto, liberta-se, toma para si "A cura através da narrativa, $[\ldots]$ o relato que o paciente faz ao médico no início do tratamento pode se tornar o começo de um processo curativo" (BENJAMIN, 2012, p. 276).

Desse modo, Frederico escreve e se liberta da culpa, como se confessasse seus medos, seus anseios e suas experiências. Através de suas memórias, do relato do seu cotidiano, dos seus sentimentos, dá-se a conhecer ao outro e, ao mesmo tempo, reflete e conhece a si. A memória, seja ela buscada ou acionada pelos sentidos, é fruto de um corpo que experienciou, que carrega as cicatrizes, os relatos, as histórias, se não somente (e puramente) os seus, os de outros, dos que são silenciados e que, por já estarem mortos, não podem mais elevar a sua voz. Escrever é manter uma ligação entre o passado e o presente; é estar no limiar do tempo, em que, ao se voltar para o passado, reflete-se e se compreende o presente. Dá, ainda, a conhecer a si ao outro, e o mesmo processo acontece com aquele que lê. Escrever transforma e esse processo só é possível pela experiência do corpo que lembra, que une os fragmentos do passado. Percebese que Frederico, ao escrever para o irmão, realiza esse processo.

Por fim, pode-se observar que a memória proporciona àquele que realiza a ação de lembrar, uma reflexão à luz do presente acerca do passado e, assim, compreender o agora. Ela é importante para conhecer a si e ao mundo em que se vive e sempre esteve associada à experiência, pois é oriunda dela. Depois das guerras e com a queda da concepção do ser racional, o narrador encontrou outras formas de perpetuar suas memórias, sendo uma delas a escrita. Esta, por sua vez, serve de linha que costura os fragmentos, as ruínas e encontra, no lixo, nos rastros, o material para compor a sua história.

Observou-se que, por meio da escrita de si, que quem escreve é Frederico Souza de Oliveira, mas que, muito mais do que sua voz, deixa ouvir outras vozes, outros tempos. Mas, acima de tudo, a escrita, como postula Foucault (2004, pp. 155-156), “[...] constitui também uma certa maneira de manifestar para si mesmo e para os outros", e assim, permite conhecer a si e ao outro em uma troca mútua de rever e refletir acerca das experiências. Isso acontece pela escrita por meio de fragmentos da história, acionados por fotos, cheiros ou lugares e pela própria ação de lembrar que funciona como uma engrenagem que busca, no passado, o material para compor e entender o presente. Foucault (2004, p.156) esclarece que "Escrever é, 'portanto, 'se mostrar', se expor, fazer aparecer seu próprio rosto perto do outro". Esse processo pode ser observado no romance de Bueno, pois é pela escrita de suas memórias que o narrador permite 
que o leitor o conheça, ao mesmo tempo em que ele reflete sobre si mesmo. Nesse sentido, a artimanha da memória é deixar transparecer aquilo que a constitui como imagem, ou seja, uma montagem do passado, que não pode ser tida como real, mas como uma mescla de realidade e imaginação, por meio da linguagem no presente. A memória é essencial para a escrita de si, pois escrever é lembrar-se de si, daquilo que o constituiu, é olhar para o passado com os pés no presente, reconhecer-se e estranhar-se e desse processo, deixar-se ver, ao mesmo tempo em que vê a si mesmo.

\section{REFERÊNCIAS BIBLIOGRÁFICAS}

AGAMBEN, Giorgio. O que é o contemporâneo? e outros ensaios. Trad. Vinícius Nicastro Honesko. Chapecó, SC: Argos, 2009.

. "O autor como gesto". In. Profanações. Trad. Selvino José Assmamm. São Paulo: Boitempo, 2007.

ANDRADE, M. Poesias completas: Volume 2, Rio de Janeiro: Nova Fronteira, 2014.

ARAÚJO, Maria Rojanski. Cachorros do céu: as transformações da fábula em Wilson Bueno. 2012. 90 f. Dissertação (mestrado) - Universidade Estadual Paulista, Instituto de Biociências, Letras e Ciências Exatas, 2012. Disponível em: <http://hdl.handle.net/11449/99129> Acesso em: 15 jun. 2016.

AZEVEDO, Anna Carolina. Crítica: Mostra Wilson Bueno/ Pinheiros e Precipícios- Festival de Curitiba. A Escotilha. 2016. Disponível em: http://www.aescotilha.com.br/teatro/interseccao/critica-mostra-wilson-bueno-pinheiros-eprecipicios-festival-de-curitiba/ Acesso em: 20 jun. 2016.

AL'HANATI, Yuri. Atando as pontas da vida. Gazeta do Povo. 2011. Disponível em: <http://www.gazetadopovo.com.br/caderno-g/atando-as-pontas-da-vida-

bkf8y0v0e89gxp5vtue9z14cu> Acesso em: 06 jul. 2017.

BAHR, Fábio; CARDOSO, Ivani. Livro inédito de Wilson Bueno apoia-se em memórias e tem traços autobiográficos. Revista Lu Fernandes. Disponível em: <http://www.lufernandes.com.br/2010/releases/livro-inedito-de-wilson-bueno-apoia-se-emmemorias-e-tem-tracos-autobiograficos-2/> Acesso em: 10 set. 2016.

BARTHES, Roland. “A morte do autor”. In. O Rumor da Língua. São Paulo: Martins Fontes, $2004 . \quad$ Disponível em: <http://grad.letras.ufmg.br/arquivos/monitoria/A_morte_do_autor_barthes.pdf> Acesso em: 05 ago. 2016.

BAUDELAIRE, Charles. O pintor da vida moderna. Concepção e organização Jérôme Dufilho e Tomaz Tadeu. Tradução e notas Tomaz Tadeu - Belo Horizonte: Autêntica Editora, 2010. BENJAMIN, Walter. "Sobre o conceito de história". In. O anjo da História. Organização e tradução de João Barreto. - 2. ed. Belo Horizonte: Autêntica Editora, 2016. 


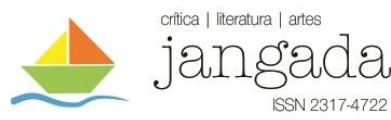

"Fragmentos" [filosofia da História e política]. In.

Organização e tradução de

João Barreto. - 2. ed. - Belo Horizonte: Autêntica Editora, 2016.

"Experiência e pobreza". In.

Organização e tradução de João Barreto. - 2. ed.

- Belo Horizonte: Autêntica Editora, 2016.

" "O narrador: considerações sobre a obra de Nikolai Leskov". In. Magia e técnica, arte e política. São Paulo: Editora Brasiliense, 1994.

Rua de Mão Única. Trad. Rubens Rodrigues Torres Filho e José Carlos Martins

Barbosa, revisão técnica Márcio Seligmann-Silva - 6. ed. Revista. São Paulo: Brasiliense, 2012.

(Obras escolhidas v.2).

BITTENCOURT, Rita Lenira de Freitas. "O espaço negociado: Mascate, de Wilson Bueno". 2016. Anais. XV ABRALIC. Disponível em:< http://www.abralic.org.br/anais/arquivos/2016_1491521928.pdf. Acesso em: 05 jun. 2017.

BLANCHOT, Maurice. O espaço literário. Trad. Álvaro Cabral. - Rio de Janeiro: Rocco. 2011. BUENO, Wilson. Mano, a noite está velha. São Paulo: Editora Planeta Brasil, 2011.

COUTINHO, Maria João. Aby Warburg e Walter Benjamin: a legibilidade da memória. Disponível em: <http://docslide.com.br/documents/aby-warburg-e-walter-benjamin-alegibilidade-da-memoria-1.html> Acesso em: 20 set. 2016.

CURY, Maria Zilda Ferreira. "Memórias da imigração". In. Palavra e imagem: memória e escritura. Márcio Seligmann-Silva (org.) Chapecó: Argos, 2006.

D’ANGELO, Biagio. "Alguns exemplos de compulsão ficcional do Eu”. Disponível em: <http://revistaseletronicas.pucrs.br/ojs/index.php/fale/article/viewFile/15464/10145> Acesso em: 19 set. 2016.

DEHAENE, Stanislas. Os neurônios da leitura: como a ciência explica a nossa capacidade de ler. trad: Leonor Scliar-Cabral. Porto Alegre: Penso, 2012.

DIDI-HUBERMAN, Georges. "Remontar, remontagem (do tempo)". Revista Étincelle. Centre Pompidou, 2007. Disponível em: < http://chaodafeira.com/wpcontent/uploads/2016/07/cad_47.pdf> Acesso em: 05 ago. 2016.

FLORENTINO, Nádia Nelziza Lovera de. Memórias, confidências e lembranças: Mar Paraguayo, de Wilson Bueno. Anais do SETA, n 4, 2010. Disponível em: < http://revistas.iel.unicamp.br/index.php/seta/article/view/902> Acesso em: 10 set. 2016.

FOSTER, Hal. "O artista como etnógrafo". In. O retorno do real: a vanguarda no final do século XX. Trad. Célia Euvaldo. São Paulo: Cosac Naify, 2014.

FOUCAULT, Michel. “A vida dos homens infames”. In: O que é um autor? Lisboa: Passagens. 1992. p. 89-128.

"A escrita de si". In: Ética, Sexualidade, Política. Trad. Elisa Monteiro, Inês Autran Dourado Barbosa. Rio de Janeiro: Forense Universitária, 2004.

“O que é um autor?". In: Estética: literatura e pintura, música e cinema. Trad. Elisa Monteiro, Inês Autran Dourado Barbosa. Rio de Janeiro: Forense Universitária, 2009. V. III.

GAGNEBIN, Jeane Marie. Limiar, aura e rememoração. São Paulo: Editora 34, 2014.

Lembrar escrever esquecer. 2. ed. São Paulo: Editora 34, 2009.

HUYSSEN, Andreas. "Em busca del futuro perdido". In: Culturas do passado-presente: modernismos, artes visuais, políticas da memória/ Andreas Huyssen; [coordenação Tadeu 


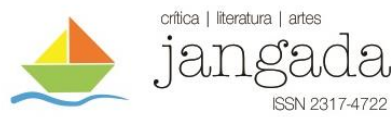

Capistrano]. Trad. Vera Ribeiro. 1. ed. Rio de Janeiro: Contraponto: Museu de Arte do Rio, 2014.

KRISTEVA, Julia. Introdução à semanálise. Trad. Lúcia Helena França Ferraz. São Paulo: Perspectiva, 2005.

MACHADO, Rosely Diniz da Silva Machado. "O sujeito discursivo e a questão da autoria". In: MITTMAN, Solange; GRIGOLETTO, Evandra; CAZARIN, Ercília. Práticas Discursivas e Identitárias: sujeito e língua. Porto Alegre: Editora Nova Prata, 2008.

MACIEL, Maria Esther. Bestiários contemporâneos: animais na poesia brasileira e hispanoamericana.

Disponível

em:

http://www.revistas.usp.br/viaatlantica/article/viewFile/50671/54783> Acesso em: 21 maio 2016.

MENDES, Ricardo. S. 40 anos do 11 de setembro: o golpe militar do Chile. Revista Estudos Políticos. 2013. Disponível em: $<$ http://revistaestudospoliticos.com/wpcontent/uploads/2014/04/7p172-190.pdf> Acesso em: 25 fev. 2017.

MITTMAN, Solange; GRIGOLETTO, Evandra; CAZARIN, Ercília. Práticas Discursivas e Identitárias: sujeito e língua. Porto Alegre: Editora Nova Prata, 2008.

MOREIRA, Bona Ricardo Caio. O encontro entre chuvosos e nefelibatas: a nuvem política. Disponível em:

http://www.dacex.ct.utfpr.edu.br/15\%20Caio\%20Ricardo\%20Bona\%20Moreira.pdf> Acesso em: 17 jun. 2016.

MOURA, Eloisa Silva. Estudo da crônica. 2008.Disponível em:< http://paginas.unisul.br/agcom/revistacientifica/artigos_2008b/eloisa_moura.pdf. Acesso em: 30 maio 2017.

NICOLAU. Curitiba: Wilson Bueno, 1987-.1994. Disponível em:< http://www.bpp.pr.gov.br/modules/conteudo/conteudo.php?conteudo=66> Acesso em: 05 de nov. 2016.

NORONHA, Lina Maria Ribeiro. O Canto Orfeônico e a construção do conceito de identidade nacional. 2009. Disponível em:< http://www2.eca.usp.br/etam/vilalobos/resumos/CO001.pdf > Acesso em: 31 maio 2017.

OLIVEIRA, Bruno Lima. A escrita de si: Genealogia. Disponível em: $<$ http://www.revlet.com.br/artigos/253.pdf> Acesso em: 20 set. 2016.

OLIVEIRA, Eduardo Jorge. Entre bestas e feras na literatura brasileira contemporânea. 2008.

Disponível

em:

http://www.abralic.org.br/eventos/cong2008/AnaisOnline/simposios/pdf/034/EDUARDO_OL IVEIRA.pdf > Acesso em: 16 jun. 2016.

OLIVEIRA, Jordânia Abadia da Silva. Artifícios da literatura contemporânea: uma memória performática?. Caderno de Pesquisa de Graduação Letras, v. 1, jan-jun, 2011. p.229-237 Disponível em: < http://anpgl.org.br/revistaeletronica/index.php/cpgl/article/view/143 Acesso em: 20 set. 2016.

OLIVEIRA. Viviane Cristina. A obra de Raul Bopp e a historiografia literária: releituras da tradição. Emblemas - $2009 . \quad$ Disponível em: https://www.revistas.ufg.br/emblemas/article/viewFile/11107/7317> Acesso em: 08 jul. 2017. 
PAIVA, Rubens. Relatório - Tomo I - Parte I - Repressão Política: Origens e Consequências do Esquadrão da Morte. Comissão da Verdade do Estado de São Paulo. Disponível em: <http://comissaodaverdade.al.sp.gov.br/relatorio/tomo-i/parte-i-cap2.html> Acesso em: 25 fev. 2017.

PAVÃO. Rodrigo. Memória e aprendizado. Laboratório de neurociência e comportamento. 2008. Disponível em:<http://www.ib.usp.br/ rpavao/memoria.pdf> Acesso em 23 out. 2016.

REIS FILHO, Daniel Aarão. Ditadura e democracia no Brasil: do golpe de 1964 à Constituição de 1998. 1. ed. Rio de Janeiro: Zahar, 2014

RICOEUR, Paul. A memória, a história e o esquecimento. Trad. Alain François [et al]. Campinas, SP: Editora da Unicamp, 2007.

SAMOYAULT, Tiphaine. A intertextualidade: memória da literatura. São Paulo: Aderaldo \& Rothschild, 2008.

SANTOS, Marcio Renato dos. Especial Nicolau - Wilson Bueno. CÂNDIDO. Jornal da Biblioteca Pública do Paraná. Disponível em: $<$ http://www.candido.bpp.pr.gov.br/modules/conteudo/conteudo.php?conteudo=649imprimir $>$ Acesso em: 19 set. 2016.

SANTOS, Rosana Cristina Zanelatto. Las (des)aventuras de la heroína de Guaratuba em Mar paraguayo, de Wilson Bueno. [200?]. Disponível em: https://drive.google.com/file/d/0BwBfN4V3pKvbUZCSmZ3VFRGNW8/view> Acesso em: 16 jun. 2016.

SARLO, Beatriz. Tempo passado: cultura da memória e guinada subjetiva. Trad. Rosa Freire d'Águilar. São Paulo: Companhia das Letras, Belo horizonte: UFMG. 2007.

SANTIAGO, Silviano. Uma literatura nos trópicos: ensaios sobre dependência cultural. 2a.ed. Rio de janeiro: Rocco, 2000.

SELIGMANN-SILVA, Márcio. Palavra e imagem: memória e escritura. Chapecó: Argos, 2006.

SILVA, Deonísio da. De onde vêm as palavras [recurso eletrônico]: origens e curiosidades da língua portuguesa. 17. Ed. Rio de Janeiro: Lexikon, 2014. Recurso digital. Disponível em:< https://books.google.com.br/books?id=P3JxBAAAQBAJ\&pg=PT1\&dq=Deonísio+da+Silva, +De+onde+vêm+as+palavras\&hl=pt-BR\&sa=X\&ved=0ahUKEwjqs5aor5vUAhVFGZAKH > Acesso em: 28 abr. 2017.

Documentário:

Operação Condor: Direção: Cleonildo Cruz. Direção, produção e roteiro: Roberto Mader. Título original: Condor. País de produção/ano: Brasil / 2007. Duração: 106 minutos. Gênero: Documentário em longa-metragem. Formato: Digital D5, 16:9, colorido. Produção: Focus Films / Taba Filmes. Distribuição: Lumière Brasil Porto Alegre - RS, 2000. 26 min. Son, Color, Formato: $16 \mathrm{~mm}$. 